\title{
Neuroimage: Giant Plexiform Schwannoma of the Penis
}

\author{
Feng Pan Bing Li Kiran jang Kunwar Qijun Zhang Yajun Xiao Fuqing Zeng \\ Department of Urology, Union Hospital, Tongji Medical College, Huazhong University of Science and Technology, \\ Wuhan, China
}

Dear Sir,

Schwannomas usually occur along the peripheral nerves but are very rare at the penis $[1,2]$. A 35-year-old man presented to our clinic seeking evaluation for a painless swelling on his penis. He had first noticed the mass 5 years before presentation; it gradually increased in size and recently interfered with sexual activity. Examination revealed a cordlike mass on the left

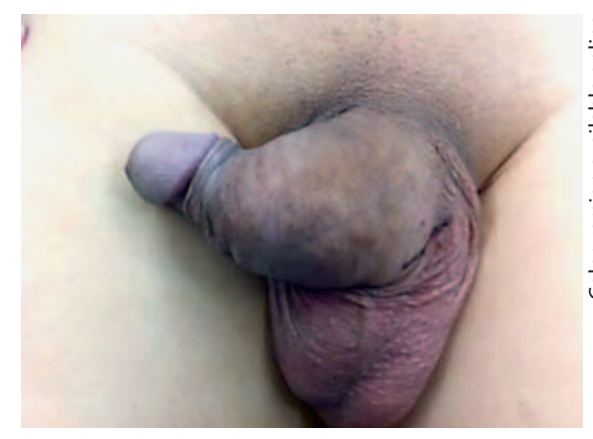

Fig. 1. The cordlike mass extended from the coronary sulcus to the root and caused a significant penile curvature. lateral side which caused penis curvature (fig. 1). Ultrasonographic examination detected a $6.0 \times 5.0 \times 2.0 \mathrm{~cm}$ hypoechoic mass with irregular margins. A pelvic CT scan showed that the tissue was located beside the left corpus spongiosum with soft tissue density (fig. 2). The postoperative pathological diagnosis was benign plexiform schwannoma.

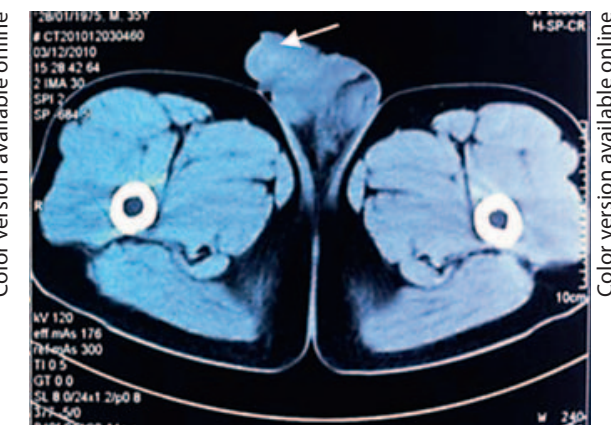

Fig. 2. The CT scan (45 HU) showed that the tissue space beside the corpus spongiosum was cloudy and thick.

\section{References}

1 Kumar GP, Sukumar S, Bhat SH, et al: Schwannoma of the penis: a common tumour at a rare site. Scand J Urol Nephrol 2006;40:166-167.

2 Loeser A, Katzenberger T, Meuller JG, et al: Solitary schwannoma of the glans penis. Urology 2007;70:1007.e5-e6.

\section{KARGER}

Fax +41613061234

E-Mail karger@karger.ch

www.karger.com
(C) 2012 S. Karger AG, Basel

0014-3022/13/0692-0118\$38.00/0

Accessible online at: www.karger.com/ene
Bing Li

Department of Urology, Union Hospital, Tongji Medical College

Huazhong University of Science and Technology

Wuhan 430022 (China)

E-Mail bingliuro@gmail.com 